Agrovoc descriptors: prunus avium; boron; foliar application; fertilizer application; flowers; buds; fruits; fertilization; plant nutrition

Agris category code: F61, F04

COBISS code 1.01

\title{
Effect of late season boron spray on boron accumulation and fruit set of 'Summit' and 'Hedelfinger' sweet cherry (Prunus avium L.)
}

\author{
Valentina USENIK ${ }^{1}$, Franci ŠTAMPAR ${ }^{2}$
}

Received: October 5, 2006; accepted June 20, 2007.

Delo je prispelo 5. oktobra 2006; sprejeto 20. junija 2007.

\begin{abstract}
The influence of late-season boron (B) application on the bud B concentration and fruit set was studied in sweet cherry (Prunus avium L.). The experiment was carried out on 5-year-old 'Summit' and 'Hedelfinger' trees on rootstock Gisela 5 in Fruit Growing centre Gačnik. Trees were sprayed with B (1\% Bortrack) or water (control). Differences in B concentration were measured between cultivars, the highest content in 'Hedelfinger' buds. Boron application resulted in increased $\mathrm{B}$ concentration in flower buds. Fruit set was influenced with cultivar, boron application and micro location. Fruit set was statistically higher in 'Hedelfinger' than in 'Summit' trees. The results showed that B fertilization had no effect on fruit set of 'Summit' despite increased concentration of boron by $94.8 \%$ in dormant flower buds. Foliar boron spraying of 'Hedelfinger' was effective in increasing B concentration (by $157.2 \%$ ) and fruit set on half trees.
\end{abstract}

Key words: sweet cherry, Prunus avium, Gisela 5, foliar nutrition, boron, flower buds, fruit set.

\section{IZVLEČEK}

\section{VPLIV FOLIARNO DODANEGA BORA V JESENI NA VSEBNOST BORA IN DELEŽ OPLODITVE PRI SORTAH 'SUMMIT' IN 'HEDELFINGER' (Prunus avium L.)}

Vpliv foliarno dodanega bora $(B) \vee$ jeseni na koncentracijo bora $v$ brstih in na delež oploditve smo proučevali pri češnji (Prunus avium L.). Poskus smo izvedli na 5 let starih drevesih sort 'Summit' in 'Hedelfinger' na podlagi Gisela 5 v Sadjarskem centru Gačnik. Drevesa smo poškropili z borom (1 \% Bortrack) ali z vodo (kontrola). Ugotovili smo značilne razlike $v$ koncentraciji bora med proučevanima sortama, večje koncentracije pri sorti 'Hedelfinger'. Foliarna prehrana z B je vplivala na večjo koncentracijo bora $v$ brstih obeh sort. Ugotovili smo, da so na delež oploditve vplivali sorta, aplikacija z borom in mikro lokacija. Delež oploditve je bil pri sorti 'Hedelfinger' značilno večji kot pri sorti 'Summit'. Foliarna prehrana z borom pri sorti 'Summit' ni vplivala na delež oploditve, čeprav se je koncentracija bora v brstih po aplikaciji povečala za $94,8 \%$. Pri sorti 'Hedelfinger' se je po škropljenju z borom

1 University of Ljubljana, Biotechnical Faculty, Department of Agronomy, Jamnikarjeva 101, Sl-1000 Ljubljana, Associate Prof., Ph. D.

2 University of Ljubljana, Biotechnical Faculty, Department of Agronomy, Jamnikarjeva 101, Sl-1000 Ljubljana, Prof., Ph. D. 
koncentracija bora $v$ brstih povečala za $157,2 \%$, delež oploditve pa je bil večji le na polovici poskusnih dreves.

Ključne besede: češnja, Prunus avium, Gisela 5, foliarna prehrana, bor, cvetni brsti, delež oploditve.

\section{INTRODUCTION}

Flower clusters have a high demand for boron (B) during blossoming if fruit set is to be fully effective (Hanson and Proebsling, 1996). Application of B sprays is often used to ensure that sufficient amounts of B are available for flower fertilization, fruit set, and early fruitlet development (Peryea, 1992; Zude et al., 1998; Hanson et al., 1985; Stover et al., 1999; Nyomora et al., 1999; Stampar et al., 1999; Solar et al., 2001). Flower buds are a preferential sink for B mobilization after foliar application (Sanchez and Righetti, 2005). Soil-applied B increased root zone soil solution B concentrations (Neilsen et al., 2004) and remained mostly in the roots while very little was translocated in the above-ground portions of the tree at full bloom (Sanches and Righetti, 2005). The tree response to foliar application of nutrients may be inconsistent (Weinbaum et al., 1988). Boron sprays after bloom increased fruit set and yield of the apple cultivar 'Elstar' (Wojcik et al., 1999). Sprays at the pink flowering stage increased flower cluster and early-season leaf B concentrations of apple 'Scarlet Gala' (Peryea et al., 2003). Application of B prior to flowering increased fruit set of olive 'Manzanillo' (Perica et al., 2001). Foliar applications of B before full bloom or after harvest increased fruit set and fruit yield of 'Conference' pear (Wojcik and Wojcik, 2003). Boron sprays and a soil B application did not increase fruit set and production of hazelnut (Ferran et al., 1997; Silva et al., 2003). Cultivars with lower tissue B concentration before B application responded more significantly to application (Hanson, 1991b; Nyomora et al., 1997).

Late season foliar spraying is an effective method of supplying B to flower buds, leaves and flowers (Hanson et al., 1985) in sour cherry (Hanson, 1991a, 1991b), apple (Zude et al., 1998), prune (Wojcik, 1999) and influences fruit set and yield of almond (Nyomora et al., 1997). In vivo pollen germination and tube growth of almond were enhanced by foliarly applied B during fall (Nyomora et al., 2000). Boron applied to trees in the autumn moves from the leaves into the adjacent buds, where elevated levels are maintained and expressed in flowers at anthesis (Hanson, 1991a; Thompson, 1996; Sanchez and Righetti, 2005). Apple shoot leaves retained, absorbed and exported at least three to four times as much foliage-applied boron as sweet cherry shoot leaves (Picchioni and Weinbaum, 1995).

Foliar B application often promotes fruit set and yield of different fruit species, but response to B application seems to be related to different factors, like species, cultivar, nutrient status,... The B requirements of sweet cherry and influence of B on sweet cherry fruit set are poorly understood. The purpose of the current study was to evaluate the possible differences in B concentration between sweet cherry cultivars and the influence of late-season B application on the flower bud B concentration. The aim of our experiment was also to determine if higher B concentrations influence the fruit set. 


\section{MATERIALS AND METHODS}

The study was conducted on 5-year-old Summit/Gisela 5 and Hedelfinger/Gisela 5 sweet cherry (Prunus avium L.) trees, planted in a single row system (900 trees/ha) and trained as a slender spindle. Cultivars 'Kordia', 'Regina' and 'Hudson' were planted in the same orchard for good pollination between cultivars. Bees were used during blooming time to ensure good pollen distribution. Trees were without visible symptoms of boron deficiency. The soil content of boron was $0.7 \mathrm{ppm}$ (Phosyn laboratories). Trial was performed in Fruit Growing centre Gačnik (Slovenia).

Foliar boron was applied 1 month prior to leaf fall ( $1^{\text {st }}$ of October 2002) on 10 trees of each cultivar. The other 10 trees served as a control and were sprayed with water. Boron application with $1 \%$ Bortrac (0.15 ppm B, Phosyn) was settled with high pressure hand-gun sprayer. At the time of B application trees had healthy leaves - flower buds on the spurs were not free from the leaves. The experimental design was 2 randomised blocks with 20 trees of each cultivar ( 5 trees per plot). The position of trees of $1^{\text {st }}$ block was upper part of the slope of the hill and the position of $2^{\text {nd }}$ block was lower part of the slope.

Dormant buds were collected in late March 2003 for boron analyses. 20 buds from different parts of the tree were sampled (1 bud per spur). Samples (buds with bracts) were oven-dried at $45{ }^{\circ} \mathrm{C}$ without washing. The dried plant material was ground to powder. Boron was extracted with $\mathrm{HNO}_{3}$ in Biotechnical faculty Ljubljana. Samples were analysed for B with ICP OES (Inductively Coupled Plasma - Optical Emission Spectrometer) on National Institute of Chemistry Slovenia.

Flowers and mature fruits were counted out on three comparable branches on three different parts of every tree 1 to $2 \mathrm{~m}$ above ground level. Fruit set was calculated from number of flowers and mature fruits on individual branches. Flowers were counted at the beginning of flowering and mature fruits at the picking time. Sweet cherry fruits were picked at commercial maturity on the basis of subjective estimation of fruit colour.

Multiway ANOVA was used for analysis the effect of factors: boron application, cultivar and micro location on boron content and fruit set. Differences between treatments were estimated with LSD test and Duncan's multiple range test $(\alpha<0.05)$. Statistical analyses were carried out using Statgraphics Plus 4.0 software (Manugistics, USA).

\section{RESULTS}

\subsection{Climatic conditions}

Climatic conditions before and during flowering are shown in Fig. 1. Figure 1 presents air temperature $2 \mathrm{~m}$ above the ground level in the period $6^{\text {th }}$ April to $30^{\text {th }}$ April 2003. In the period from April 6 to 9 spring cool spell $\left(\mathrm{T}_{\min }-4.8^{\circ} \mathrm{C}\right)$ passed Slovenia which coincided with phenological stage bud bursting (first swell to side green) of sweet cherry. During full bloom the temperatures were rather low for effective pollination. After the flowering (in May) the climate was very dry, average temperatures were for $2^{\circ} \mathrm{C}$ higher than long term temperatures. 


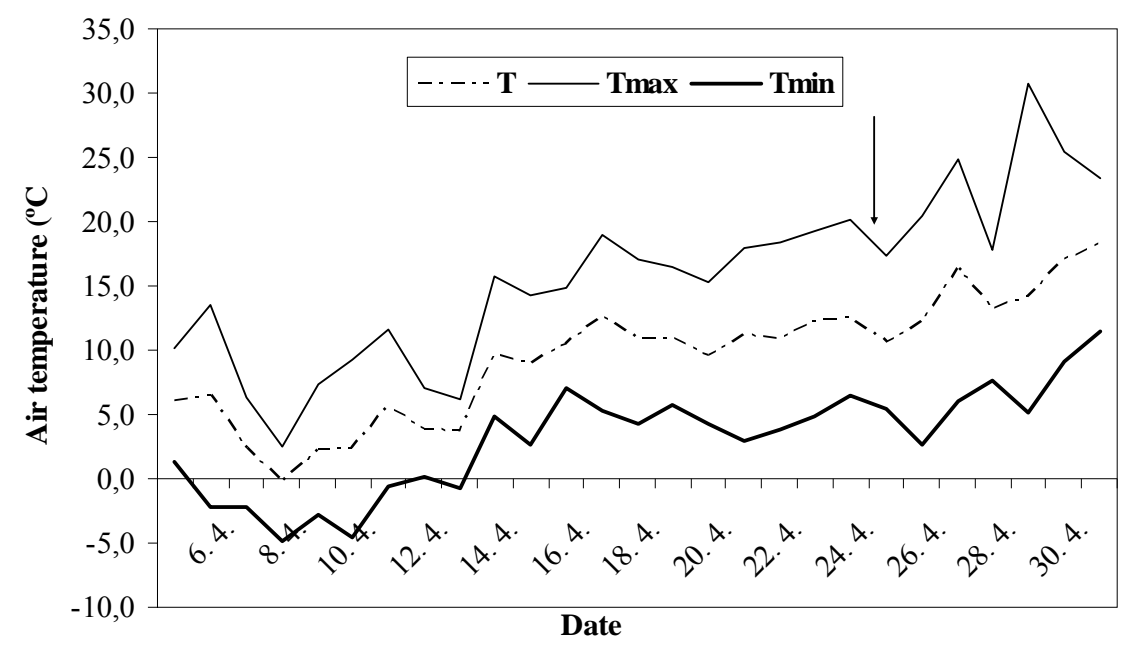

Fig. 1: The daily temperature data in the period $6^{\text {th }}$ April to $30^{\text {th }}$ April 2003 in Fruit growing centre Gačnik. Vertical arrow presents the phenological stage first bloom of sweet cherries.

\section{2 Boron concentrations}

Differences in boron concentration in dormant flower buds were statistically significant between cultivars (Tables 1 and 2). The average boron concentration in control trees of 'Summit' was $127.4 \mu \mathrm{gg}^{-1}$ dry wt and $226.2 \mu \mathrm{gg}^{-1}$ dry wt in 'Hedelfinger'. The single boron application resulted in higher boron content in 'Summit' (Table 1) and 'Hedelfinger' dormant buds (Table 2). Boron concentrations were similar in different blocks. Only in control 'Summit' trees there were higher boron concentration in Block II. Boron spray increased B concentration in 'Summit' buds by $94.8 \%$ and in 'Hedelfinger' buds by $157.2 \%$. The average boron concentration in treated trees of 'Summit' was $248.2 \mu \mathrm{gg}^{-1}$ dry wt and in

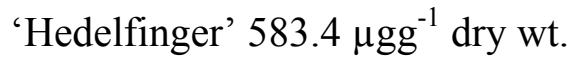

Table 1. Average B concentrations ( $\mu \mathrm{gg}^{-1}$ dry wt) in dormant 'Summit' sweet cherry flower buds. Values followed by a different letter are significantly different at $\alpha<0.05$ by LSD test.

\begin{tabular}{llcc}
\hline & & Block I & Block II \\
\hline Summit & Boron & $267.2 \pm 14.7 \mathrm{a}$ & $224.5 \pm 20.84 \mathrm{a}$ \\
& Control & $117.6 \pm 4.7 \mathrm{c}$ & $137.2 \pm 6.1 \mathrm{~b}$ \\
\hline
\end{tabular}

Table 2. Average B concentrations ( $\mu \mathrm{gg}^{-1}$ dry wt) in dormant 'Hedelfinger' sweet cherry flower buds. Values followed by a different letter are significantly different at $\alpha<0.05$ by LSD test.

\begin{tabular}{llcc}
\hline & & Block I & Block II \\
\hline Hedelfinger & Boron & $494.0 \pm 120.0 \mathrm{a}$ & $636.8 \pm 141.6 \mathrm{a}$ \\
& Control & $266.7 \pm 36.9 \mathrm{~b}$ & $197.0 \pm 40.7 \mathrm{~b}$ \\
\hline
\end{tabular}




\subsection{Fruit set}

The number of flowers per branch was in 'Summit' and 'Hedelfinger' trees similar in all treatments. The number of 'Summit' fruits per branch was in Block I statistically higher than in Block II. Average number of 'Hedelfinger' fruits per branch in boron treated trees was statistically higher in Block I, in control trees there were no differences between blocks (data not shown).

The results show higher fruit set for 'Hedelfinger' than for 'Summit' sweet cherry. Boron application of 'Summit' sweet cherry trees resulted in similar fruit set in both treatments and both Blocks (no positive effect on fruit set). Fruit set was statistically higher only in control 'Summit' trees in Block I. Fruit set of boron treated 'Hedelfinger' sweet cherry trees was higher than of control trees only in Block I. Fruit set of 'Hedelfinger' in Block II was lower than in Block I, similar to control trees in Block I (Fig. 2).

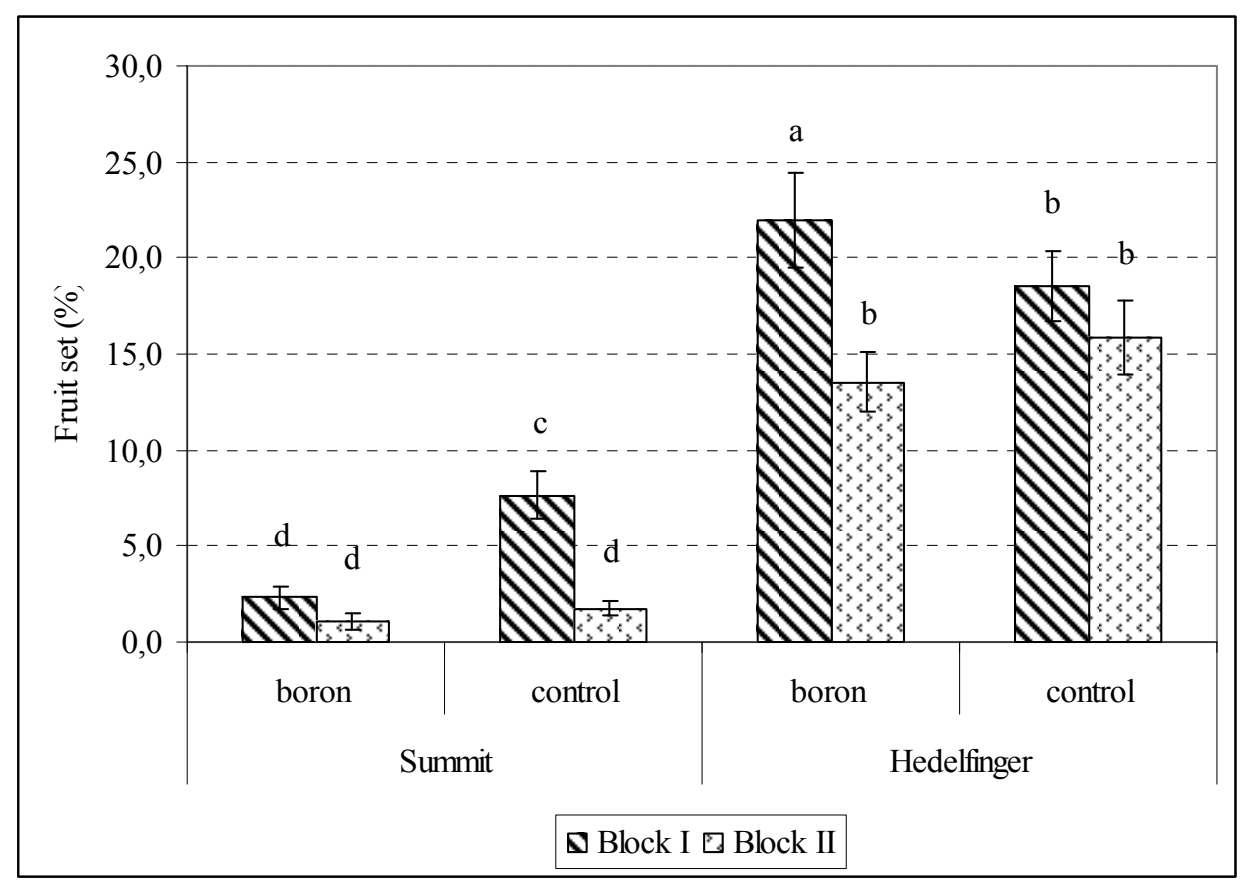

Figure 2: Fruit set (\%) of 'Summit' and 'Hedelfinger' sweet cherries of different treatments and blocks. Values followed by a different letter are significantly different at $\alpha<0.05$ by Duncan's multiple range test.

\section{DISCUSSION}

Single B product was used in our trial, because different B products resulted in similar flower cluster B content in apple (Peryea, 2005). The content of boron in sweet cherry dormant buds in our experiment was rather higher than content of B in sour cherry 'Montmorency' in Michigan (Hanson, 1991b). The differences in B content can be ascribed to different species and also to the rootstock used. B nutritional status of apple trees is influenced by a rootstock (Wojcik et al., 2003) and can holds true also 
for different sweet cherry rootstocks as well. Rootstock genotypes affect sweet cherry vegetative and generative development (Usenik et al., 2006) but there are no data about the influence of rootstock on B nutritional status in sweet cherry. Analyses of boron content were made in flower buds because they can be used to predict B nutritional status of apple trees (Wojcik, 2002).

Different B concentrations were measured in 'Summit' and 'Hedelfinger' dormant flower buds. The concentration of boron in control 'Hedelfinger' trees were even higher than in 'Summit' trees after boron application. Application with boron in our trial resulted in similar increase of B like in sour cherry buds (Hanson, 1991b). Our results show that fall foliar $\mathrm{B}$ application is an effective method to enlarge boron concentration in sweet cherry dormant buds, like in apple (Zude et al., 1998), prune (Wojcik, 1999) and sour cherry (Hanson, 1991b).

'Summit' fruit set was very low, it was less-than-optimum. Low fruit set could be influenced by several factors: young trees, fruiting habit of cultivar 'Summit' (Bargioni, 1996), climatic conditions during bud swelling (Fig. 1). $\mathrm{T}_{\min }$ reached -4.8 ${ }^{\circ} \mathrm{C}$ when sweet cherry trees were in phenological stages first swell to side green. Critical temperatures for these phases have been established for 'Bing' sweet cherry, from -11.1 to $-5.8^{\circ} \mathrm{C}$ (Thompson, 1996). The number of 'Summit' fruits per branch was in Block I statistically higher than in Block II which can be explained with the influence of micro location on bad pollination. On the basis of our results for 'Summit' we cannot confirm the statement that response to B application appears to be better in years when fruit set is low (Nyomora et al., 1999; Perica et al., 2001; Hanson in Breen, 1995; Shrestha et al., 1987; Usenik and Štampar, 2002) because boron foliar application had no influence on 'Summit' fruit set. Micro location and cultivar characteristics had greater influence. Other unknown factor(s) may ultimately determine the percentage of fruits that remain on the tree at harvest (Nyomora, 1999).

Fruit set of 'Hedelfinger' sweet cherry was statistically higher than in 'Summit' sweet cherry. Fruit set of control and with B treated 'Hedelfinger' trees was sufficient for yield of good quality fruits. Boron application had positive effect on 'Hedelfinger' fruit set in Block I. Fruit set of boron treated 'Hedelfinger' sweet cherry trees was statistically higher than in control trees in Block I and higher than fruit set in both treatments in Block II. Our results in 'Hedelfinger' show that nutrition with boron can be effective (but inconsistent) also in cultivars with higher B concentrations. Nutrition with boron can be more effective in conditions where trees were supplied inadequate or in cultivars with lower tissue B concentration (Hanson, 1991b, Nyomora et al., 1997).

Our results show that the tree response to foliar application of nutrients is also in sweet cherry inconsistent (Weinbaum et al., 1988) and depends on different factors. Assuring a good nutritional status of the floral buds may overcome bad climatic conditions (Sanzol, 2001). Single foliar boron application is effective in increasing B concentration in flower buds, higher B concentrations however can improve fruit set in sweet cherry, so the possible positive effects can easly cover the costs. Nutrition with boron can be more useful especially when fruit set is low and can be in function of controlling tree vigour (medium productive cultivars on vigorous rootstocks). Rootstock Gisela 5, used in our experiment, is early-bearing and very productive 
rootstock. There is a potential problem of excessive cropping (especially in combination with very productive cultivars) which can result in poor fruit quality and poor vegetative growth (Long, 2001). So caution is needed. Further studies of B requirements and influence of boron on sweet cherry yield are needed, especially when new technologies (cultivars, rootstocks, training systems) have been introducing.

\section{REFERENCES}

Bargioni, G. 1996. Sweet Cherry scions: Characteristics of the Principal Commercial Cultivars, Breeding Objectives and methods. In: A. D. Webster and N. E. Looney (eds.), Cherries: crop physiology, production and uses', CAB International, Wallingford: 73112.

Ferran, X., Tous, J., Romero, A., Lioveras, J., Pericon, J.R. 1997. Boron does not increase hazelnut fruit set and production. HortScience 32: 1053.

Hanson, E.J. 1991a. Movement of boron out of tree fruit leaves. HortScience 26: 271.

Hanson, E.J. 1991b. Sour cherry trees respond to foliar boron applications. HortScience 26: 1142.

Hanson, E.J., Breen, P.J. 1995. Effects of fall boron sprays and environmental factors on fruit set and boron accumulation in 'Italian' prune flowers. Journal of American Society for Horticultural Science 110: 389.

Hanson, E.J., Chaplin, M.H., Breen, P.J. 1985. Movement of foliarly applied boron out of leaves and accumulation in flower buds and flower parts of 'Italian' prune. HortScience 20: 747.

Hanson, E.J., Proebsling, E.L. 1996. Cherry nutrient requirements and water relations. In: A. D. Webster and N. E. Looney (eds.), Cherries: crop physiology, production and uses', CAB International, Wallingford, UK: 243-257.

Long, L. 2001. Sweet cherry training systems. The Compact Fruit Tree 34: 66.

Neilsen, G.H., Neilsen, D., Hogue, E.J., Herbert, L.C. 2004. Zinc and boron nutrition management in fertigated high density apple orchards. Canadian Journal of Plant Science 84: 823.

Nyomora, A.M.S., Brown, P.H., Freeman, M. 1997. Fall foliar-applied boron increases tissue boron concentration and nut set of almond. Journal of American Society for Horticultural Science 122: 405.

Nyomora, A.M.S., Brown, P.H., Krueger, B. 1999. Rate and time of boron application increase almond productivity and tissue boron concentration. HortScience 34: 242.

Nyomora, A.M.S., Brown, P.H., Pinney, K., Polito, V.S. 2000. Foliar application of boron to almond trees affects pollen quality. Journal of American Society for Horticultural Science 125: 265.

Perica, S., Brown, P.H., Connell, J.H., Nyomora, A.M.S., Dordas, C., Hu, H.N., Stangoulis, J. 2001. Foliar boron application improves flower fertility and fruit set of olive. HortScience 36: 714.

Peryea, F.J. 1992. History of boron research in apples, pears reviewed. Good Fruit Grower, 43, 26-29.

Peryea, F.J. 2005. Comparison of commercial boron spray products applied at the pink flowering stage on 'Fuji' apple. Hortscience 40: 1487. 
Peryea, F.J., Neilsen, D., Neilsen, G. 2003. Boron maintenance sprays for apple: Early-season applications and tank-mixing with calcium chloride. Hortscience 38: 542.

Picchioni, G.A., Weinbaum, S.A. 1995. Retention and the kinetics of uptake and export of foliage-applied, labelled boron by apple, pear, prune and sweet cherry leaves. Journal of American Society for Horticultural Science 120: 28.

Sanches, E.E., Righetti, T.L. 2005. Effect of postharvest soil and foliar aplication of boron fertilizer on the partitioning of boron in apple trees. Hortscience 40: 2115.

Sanzol, J. 2001. The "effective pollination period" in fruit trees. Scientia Horticulturae 90: 1.

Shrestha, G.K., Thompson, M.M., Righetti, T.L. 1987. Foliar - applied boron increases fruit set in 'Barcelona' hazelnut. Journal of American Society for Horticultural Science 112: 412.

Silva, A.P., Rosa, E., Haneklaus, S.H. 2003. Influence of foliar boron application on fruit set and yield of hazelnut. Journal of Plant Nutrition 26: 561.

Solar, A., Štampar, F. 2001. Influence of boron and zinc application on flowering and nut set in 'Tonda di Gifoni' hazelnut. Acta Horticulturae 556: 307.

Štampar, F., Šturm, K., Hudina, M., Usenik, V. 1999. Influence of foliar fertilization on yield quantity and quality of apple (Malus domestica Borkh.). In: Anac, D., Martin-Prével, P. (eds.). Improved crop quality by nutrient management. Dordrecht, Kluwer Academic Publishers: 91-94.

Stover, E., Fargione, M., Risio, R., Stiles, W., Iungerman, K. 1999. Prebloom foliar boron, zinc and urea applications enhance cropping of some 'Empire' and 'McIntosh' apple orchards in New York. HortScience 34: 210.

Thompson, M. 1996. Flowering, pollination and fruit set. In: A. D. Webster and N. E. Looney (eds.), Cherries: crop physiology, production and uses', CAB International, Wallingford: 223-241.

Usenik, V., Fajt, N., Štampar, F. 2006. Effects of rootstocks and training system on growth, precocity and productivity of sweet cherry. The Journal of Horticultural Science \& Biotechnology 81: 153.

Usenik, V., Štampar, F. 2002. Effect of foliar application of zinc plus boron on sweet cherry fruit set and yield. Acta Horticulturae 594: 245.

Weinbaum, S.A. 1988. Foliar nutrition of fruit trees. In: Plant growth and leaf applied chemicals. CRC Press, Inc. Boca Raton, Florida, USA: 81-100.

Wojcik, P. 1999. Effect of boron fertilization of 'Dabrowicka' prune trees on growth, yield, and fruit quality. Journal of Plant Nutrition 22: 1651.

Wojcik, P. 2002. Boron analysis in tissues before apple tree bloom can be used to assess boron nutritional status. Journal of Plant Nutrition 25: 1011.

Wojcik, P., Wojcik, M., Treder, W. 2003. Boron absorbtion and translocation in apple rootstocks under conditions of low medium boron. Journal of Plant Nutrition 26: 961.

Wojcik, P., Wojcik, M. 2003. Effect of boron fertilization on 'Conference' pear tree vigor, nutrition, and fruit yield and storability. Plant and Soil 256: 413.

Zude, M., Alexander, A., Lüdders, P. 1998. Influence of boron spray in autumn or spring on flower boron concentration, fruit set and yield in apple cv. Elstar. Erwerbsobstbau 40: 18. 